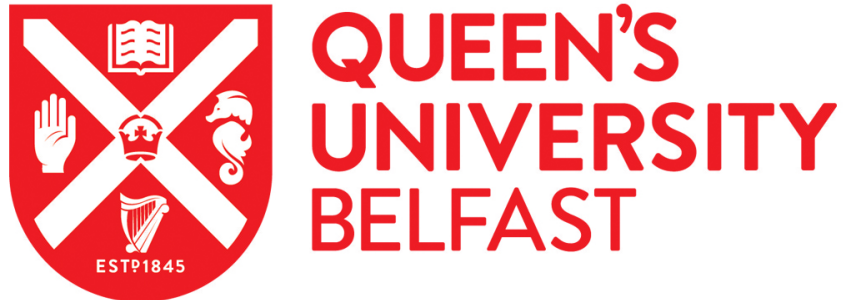

\section{Schools, communities and the police - shared education as a mechanism for social cohesion and community safety}

Duffy, G., \& Gallagher, T. (2020). Schools, communities and the police - shared education as a mechanism for social cohesion and community safety. Education and Society, 38(2), 37-61. https://doi.org/10.7459/es/38.2.04

Published in:

Education and Society

Document Version:

Peer reviewed version

Queen's University Belfast - Research Portal:

Link to publication record in Queen's University Belfast Research Portal

\section{Publisher rights}

Copyright 2020 James Nicholas Publishers.

This work is made available online in accordance with the publisher's policies. Please refer to any applicable terms of use of the publisher.

\section{General rights}

Copyright for the publications made accessible via the Queen's University Belfast Research Portal is retained by the author(s) and / or other copyright owners and it is a condition of accessing these publications that users recognise and abide by the legal requirements associated with these rights.

Take down policy

The Research Portal is Queen's institutional repository that provides access to Queen's research output. Every effort has been made to ensure that content in the Research Portal does not infringe any person's rights, or applicable UK laws. If you discover content in the Research Portal that you believe breaches copyright or violates any law, please contact openaccess@qub.ac.uk. 


\title{
Schools, communities and the police - shared education as a mechanism for social cohesion and community safety.
}

\section{Dr Gavin Duffy \& Prof Tony Gallagher, Queen's University Belfast}

Correspondence: g.duffy@qub.ac.uk

School of Social Sciences, Education and Social Work

6 College Park

Queen's University Belfast

Belfast

BT7 1PS

\begin{abstract}
The relationship between the police and communities can be difficult in ethnically divided societies, especially if membership of the police force is largely drawn from one community. This situation pertained in Northern Ireland which has separate schools for different religious communities. Despite a major reform of the police after the signing of the Good Friday Agreement (1998) the relationship between the police and the Catholic minority remained difficult and, in particular, the police found it difficult to engage with pupils in some Catholic schools. An education initiative, called Shared Education, was launched in 2006 to support the peace process by encouraging collaborative partnership between Protestant and Catholic schools. This paper examines a school partnership in Northern Ireland in which statutory and non-statutory organisations, including the Police Service in Northern Ireland, were involved. The paper examines how the relationship between the police and the schools was enabled by the collaborative partnership: in particular, it allowed the police to provide information and advice to parents on internet safety and cyber-bullying to parents with whom it would otherwise have been very difficult to engage.
\end{abstract}

Keywords: Education, Police, Partnership, Divided Societies

\section{Introduction}

Police work in schools for many reasons, including educational value, improving relationships between the police and young people, promoting awareness of the role of the police, or improving the quality and impact of community policing more generally. The mode of engagement by police can vary through such means as ad-hoc visits, school invites, formal assignment of an officer to a school, or assignment to a larger network of schools in a community. This paper explores the nature of police-school engagements in contexts where policing is politically contentious. This 
occurs in ethnically divided societies where the police force has traditionally drawn its members from one community. Northern Ireland provides a particularly good example of this genre.

Religious, national and political divisions in Northern Ireland precipitated a violent political conflict which began in the 1960s and ended with a political settlement in 1998. The violence has largely ended, but politics retains a confessional character and the religio-political fault-line remains strong. Divisions are also institutionalised through schools as parallel de facto denominational systems have operated and, for the most part, Catholic and Protestant students are educated separately, tempered only by a small $(7 \%)$ religiously integrated system (Gallagher and Duffy, 2016).

Another institutional manifestation of community division in Northern Ireland is provided by the policing service. The Royal Ulster Constabulary (RUC) was formed in 1922 when Northern Ireland became a self-governing region within the United Kingdom. Although it inherited members from the old Royal Irish Constabulary (RIC) membership of the RUC was dominated by members of the Protestant community, and throughout its history, the relationship between the RUC and the Catholic minority in Northern Ireland has been, at best, fractious (Ellison, 2000; Ellison and Mulcahy, 2001).

It was not surprising, therefore, that one key element of the peace process involved an independent review of policing in Northern Ireland (Patten Report, 1999). The Review group made widespread recommendations for change in policing, including the establishment of a special recruitment procedure so that 'an equal number of Protestants and Catholics should be drawn from the pool of qualified candidates' (Patten Report, 1999: para 15.10: 88). The intention was to create a new police service that would reflect the society in which it was based and which would gain the respect and trust of the entire community: this system started in 2001 and was ended in 2011, at which point 30 per cent of PSNI members were Catholic (in the 1990s only about seven per cent of the RUC was Catholic).

The Patten report noted that the problems facing policing in Northern Ireland had many features unique to divided societies, although there were some issues that were common to policing in all democratic societies, particularly in relation to shifting the culture of policing away from being a 'force' to becoming a 'service'. One of the unique challenges noted in their consultation process was the way people could, at times, evaluate policing in terms of the quality of the service it provided, but at other times evaluated it using political considerations:

'the views people express about the police are often essentially political views about the RUC as an institution rather than views about the policing service which they themselves receive.' (Patten Report, 1999: para 3.6: 13)

One consequence of the historical discord between the Catholic minority and the police was their restricted access to Catholic schools in some areas. The Patten Report suggested that the police were unable to liaise with as many as a quarter of all schools (Patten Report, p. 86). The report made various recommendations which encouraged engagement of schools with the intentions of improving relationships, familiarisation, and encouraging recruitment. The PSNI since then have developed educational and community safety orientated programmes for schools as well as work experience programmes, but school engagement is more likely to take place in Protestant rather than Catholic schools as some communities resist the presence of the police in Catholic schools. 
There are a few studies which explore the relationship between young people of school age and the police in Northern Ireland and these tend to focus on perceptions of the legitimacy of policing (see the Young Person's Behaviour and Attitudes Survey, NISRA, 2007; Devaney et al., 2014, Nelson et al., 2010; Hamilton et al., 2003) rather than explore the impact of police engaging with schools, teachers and students. Despite this, schools remain as one of the most likely places where young people and the police will interact. The potential for schools to engage with the police, while avoiding the problems arising from this dualistic way of evaluating the role of the police, forms the centre-piece of the case study explored in this paper.

The case study involves eight Protestant and Catholic schools which developed a collaborative partnership, the Foyle Contested Spaces Partnership (FCSP), to address a range of social issues facing young people. These schools were involved in the Shared Education initiative that has been in place in Northern Ireland since 2007. The aim of Shared Education is to foster collaborative partnerships between Protestant and Catholic schools to promote school improvement and community cohesion (Gallagher, 2016). FCSP provided an example of school collaboration where the role of the police, and the way it engaged with the community, proved to be significant. Furthermore, it seemed to provide a way to address the dualistic way that the role of the police is evaluated in Northern Ireland.

Before looking at the experience provided by our case study we want to examine some of the broader characteristics of school-police engagement in arrange of jurisdictions.

\section{The role of police in schools in the US and Britain}

Stinson and Watkins (2014) show that the use of sworn police officers in schools dates back to the 1950s, but this has grown significantly since the late 1970s, not least school campus shootings have thrown the issue of school safety into sharp relief. The Everytown Research Group (2016) highlighted that there had been 186 school shootings between 2013 and 2015 leading to 59 deaths and 124 non-fatal gunshot wounds. Almost 53 percent of shootings took place in K-12 schools and 47 percent on college or university campuses. As a consequence, there had been a rise in the use of School Resource Officers (SRO). SROs were working in 43 per cent of all public schools in the United States (Zhang, et al., 2015) and the Office of Community Policing Services funded 17,000 SROs nationally (James and McCallion, 2013). There has been an increase in the use of metal detectors and surveillance cameras. Theriot (2009) contended that such measures were also fuelled by public fear that juvenile and school related crime was rising, despite evidence to the contrary. School shootings and school related crime notwithstanding, the remit of SROs appeared to be much broader. While SROs address crime and disorder, law enforcement, patrolling and securing the school campuses, they also focus on drug awareness, the development of community justice, conflict resolution or restorative justice practices, and act as a liaison between school and community services. At times they also assisted teachers in more educationally oriented activities, such as helping with student behaviour and attendance.

Police-school initiatives in England and Wales emerged from discussions between educators and criminologists in the 1980s on the need to address challenging and unruly behaviour in schools, and improve school safety (Brown, 2006). High profile incidents, such as the murder by a 15-year old student of school Principal Philip Lawrence in 1995, also played a role (Police Foundation, 2011). Various initiatives have been tried (see Hopkins et al., 1992; Hopkins, 1994; Bhabra et al., 2004; Brown, 2006; Lamont et al., 2011) including the establishment of Safer School Partnership Officers or School Liaison Officers (Police Foundation, 2011; Trotman and Thomas, 2016; Lamont et al., 2011; Clayman and Skins, 2012) and the All Wales School Liaison School Core 
Programme (Stead et al., 2011). Safer School Partnerships are formalised agreements between schools, or groups of schools, and various statutory/voluntary agencies, including the police, to make schools safer, reduce crime and promote positive behaviours in young people. Typically, a Police Community Support Officer (PCSO) will be appointed to a school on a part or full time basis. Lamont et al. (2011: 8) identified different degrees of connection police had with their schools: an 'active' connection, where the officer had a dedicated role in a school; a 'flexible' connection, where the officer worked as part of team serving one or more schools; 'formal and responsive' connections, where the officer operates as a named contact for the school; 'informal and responsive' connections, where an officer provides for a school as part of their normal policing responsibilities; and finally a 'single purpose' connection, when an officer works with a school, on a time-limited basis, to address a specific need.

\section{Evaluating police in school initiatives}

Various commentators (Theriot, 2009; Petteruti, 201; Na and Gottfredson, 2011) have raised concerns that police-school initiatives can increase the likelihood of children becoming criminalised simply because of additional scrutiny: they suggest this may lead to more arrests and increased referrals to justice systems. Na and Gottfredson (2011) compared US schools that used, or did not use, SROs. Typically, schools that did not use SROs were less likely to report students to the authorities. By contrast, schools with SROs were more likely to report non-serious violent offences. Petturti (2011: 1) argued that a police presence in schools may 'disrupt the educational process and can lead to suspension, expulsion, or other alienation from school.'

In Britain Lamont et al., (2011: iv) argued that officers found the role of policing in schools to be very different from policing in the community in that it involved a steep learning curve where officers needed to find a balance between 'keeping a police head' on and being aware of the needs of schools and not criminalising students.' Similarly, both Frondigoun et al. (2013) and Black et al. (2010) described how the role of police officers in school was often ill-defined or ambiguous. Additionally, the literature points to an emerging ambiguity and tension about who is responsible for school discipline and highlighted concerns that police officers were not adequately trained in educational theory or practice to adequately deal with the type of discipline issues dealt with by teachers (Brown, 2006, Stinson \& Watkins, 2014; Theriot, 2009).

Some studies reported positive benefits of police in schools. Theriot (2009) found that SROs reduced the number of arrests involving assaults and weapons. Black et al. (2010) and Frondigoun et al. (2013) reported that the relationship between students and the police improved, although Black et al. highlighted that this did not extend beyond the school into the community. Clayman and Skins (2012: 468) found that police in schools enabled officers to become accessible to students and, more importantly, provided a familiar face.

Black et al. (2010) highlight that information sharing between police and the school improved and that police and educators held common views that police in schools fostered a sense of increased safety, leading to reductions in indiscipline, violence and criminal activity. Frondigoun et al. (2013) suggested that this work changed young people's perceptions of the police and pointed to a rise in student interest in applying for work experience in the police, or even applying to become police officers. Similarly, Clayman and Skins (2012: 476) suggested that a positive relationship with police officers 'from a procedural justice perspective is the first step towards acquiring legitimacy, which in turn may lead to active cooperation.' 
While some expressed concerns about the ambiguity of the role of police officers in schools, others argued that a new type of public servant was emerging that improved the connections between school and community. Frondigoun et al. (2013) described campus officers as a 'hub' or 'focal point' for community based services that wished to liaise with children in school. Similarly, Brown et al. (2006: 600), commenting on U.S. schools, suggested that police officers represented a new species of public servant 'who perform an amalgam of educational, correctional, law enforcement' duties.

\section{Catholic schools and the police in Northern Ireland}

How has this difficult relationship with the Police in Northern Ireland and the Catholic minority been affected by the peace process over the past two decades? Police officers in Northern Ireland have never been stationed in schools and will only visit when invited. Police mostly play an educational role in schools, and the nature and type of their engagement is governed by a formal set of policies and guidelines (PSNI, 2016 CCMS, 2011b). The PSNI have developed the Citizenship and Safety Education Programme (CASE) which is delivered in schools across Northern Ireland by Community and Schools Officers. The programme addresses a range of topics including community safety, anti-social behaviour, youth engagement and internet safety. The CASE Programme has four key aims:

- to contribute to the preparation of young people in their transition to adult life;

- to promote within young people attitudes, values and skills for personal and social development and positive citizenship;

- to promote mutual understanding and respect between young people from different groups; and

- to establish and reinforce productive and positive contact between Police Officers and young people through schools. (PSNI, 2009)

These themes align with the Northern Ireland Curriculum for schools which explore themes related to personal development, mutual understanding, learning for life and work and citizenship (CCEA, 2016; 2016a).

In 2009 the PSNI conducted an equality impact assessment of the CASE programme. The report highlighted that, while the CASE programme was available to all schools upon request, Catholic schools were less likely to request it, compared with Protestant schools (PSNI, 2009). Devaney et al. (2014) found that Protestant students, compared with Catholic students, were twice as likely to have encountered the police as part of a school visit (see also Nelson et al. 2010). The PSNI report further concluded that, where local community voting trends were mostly nationalist or republican, schools were less likely to request the CASE programme. In response the report recommended further research with the principals of schools not participating in CASE and active promotion of the programme in areas where it did not operate in order to increase the number of Catholic schools participating (PSNI, 2009: 21-22).

The Catholic Church and the Council for Catholic Maintained Schools (CCMS) have, as part of a peace building strategy, developed a strategic partnership with the PSNI, the aim of which was to 'improve relationships between our schools and the PSNI and to work to improve the education, safety and opportunities for our children and young people and contribute to the normalisation of society,' (CCMS, 2011a: 1). A circular informed Principals that a CCMS/PSNI working group had been established and highlighted the need for Catholic schools to have more information on their 
local PSNI officers and specific contacts to discuss issues regarding community safety and child protection issues (CCMS, 2011a).

The initiative was covered by national, local and social media outlets and provoked some controversy. BBC journalist, Taggart (2011), reported that just over 100 schools were involved and identified a number of priority areas for further development. Local newspapers and social media highlighted some parent and community to the initiative, while one national newspaper reported that parents in 'hard-line republican areas of Derry are up in arms that the PSNI have been invited into Catholic schools to try to recruit their kids,' (Sunday World, 2011).

In November 2011, a second circular was sent out to all schools and appeared to respond to some of the concerns raised, emphasising that 'the priority for this joint initiative is to ensure that children have access to suitable information related to the curriculum, and for their safety and protection' (CCMS, 2011b). The circular also outlined a code of conduct for officers in Catholic schools emphasising a number of key principles for practice:

- While an officer is in the classroom, the teacher must remain present at all times. Should a teacher be called out of the classroom for any reason, he/she must arrange for an appropriate member of staff to be in the classroom during the officer's visit.

- Should a parent object to a police officer delivering a CASE Programme lesson, the school should facilitate the child being removed from the classroom.

- If, in his/her course of duty, an officer has cause to visit a school for a reason other than CASE delivery, this reason will be clearly stated to the school staff.

- An officer delivering the CASE Programme will have successfully completed the relevant training provided by Community Safety Branch of the Police Service of Northern Ireland. (CCMS, 2011b)

In a circular issued in November 2012, CCMS (2012/26) schools were further encouraged to engage with the police and highlighted opportunities for students to take part in a pilot work experience programme at the police training college. It was clear, therefore, that engagement between the police and Catholic schools remained problematic and, at times, challenging, as the political legacies of the past remained potent. This was the context in which the Shared Education initiative and school collaboration provided a different way in which schools and the PSNI might cooperate.

\section{Shared Education in Northern Ireland}

Schools in Northern Ireland are divided into parallel denominational systems with separate sectors for Protestant and Catholic students, and a small sector of religiously integrated schools. The denominational character of the schools reflects governance and ownership arrangements: there are no formal religious tests on entry, but most parents choose schools from their own community (Akenson, 1970; 1973; Gallagher 2016). During the years of political violence there were a range of school based interventions aimed at promoting reconciliation or equality, including the development of common curriculums and textbooks, contact initiatives, the development of new integrated schools and equal funding for Catholic schools, although their efficacy in promoting systemic change was limited (Gallagher, 2004). In the context of the peace process a new initiative emerged in 2006, known as Shared Education which involved Protestant, Catholic and integrated schools working collaboratively in local areas to promote sustained and regular contact between students and teachers. Under this initiative, students take classes in each other's schools and educators cooperate in order to make this educationally and socially effective. Ideally, 
collaboration is focused on high value, core curricular subjects, aimed at widening opportunity and choice, and promoting school improvement and social cohesion.

There were two main phases of the Shared Education Programme (SEP). SEP1 operated between 2007 and 2010 and involved 65 schools in 12 collaborative partnerships; SEP2 operated between 2010 and 2013 and involved 80 schools in an additional 12 partnerships. From 2013 onwards some support work continued with these and other schools, including the case study at the heart of this paper, but the balance of attention shifted to mainstreaming the approach so that future partnership work was supported by the Education Authority through the Shared Education Signature Project (SESP) (Gallagher, 2016; Duffy \& Gallagher, 2017; Duffy and Gallagher, 2015; Hughes \& Loader, 2015; Loader, 2015; Robinson, 2016). Currently about three-quarters of schools in Northern Ireland are involved in SESP or partnership programme supported by European Union Peace Funding. Shared Education was made a statutory duty through the Education Act (Northern Ireland) (2014) and the Shared Education Act (2016).

\section{Introducing the Foyle Contested Space Partnership}

A distinctive SEP school partnership began in the same month as the launch of the strategic partnership between the PSNI and CCMS, (Duffy and Gallagher, 2017; 2015). The Foyle Contested Space Partnership ${ }^{1}$ involved eight schools in the city of Derry/Londonderry, five primary schools and three post primary schools, four of which were Protestant and four Catholic. This was part of a broader initiative which encouraged schools and third sector organisations to address need, encourage reconciliation and contribute to better outcomes for children, young people and families living in interface areas. From September 2011 to June 2014 a total of 1,161 students, aged 8 to 15 years, were involved in weekly shared lessons within the partnership; students travelled to each other schools and took classes together. A total of 35 teachers, including all eight principals, were involved in the management, coordination and teaching within the partnership; the primary teachers were also supported by an external co-ordinator, the vast majority of which were interviewed in the course of our evaluation of the program.

The project required that the schools identify a range of interventions that were relevant to their local and social context and would impact on the wider aims of the initiative. When they met to agree an agenda of action in 2011, the teachers and school leaders agreed that it was important for students to explore themes such as identity and community relations, given the contested nature of the city: the communities in Derry/Londonderry are divided by a river, have a long history of antagonism and, as is perhaps evident, disagree even on the name of their city.

It would be lovely to be able to say these are young children who don't know what we went through in the past and therefore shouldn't have any of these issues. But, the reality is that they are growing up in families who did come through these troubled times and have a big influence on their children. (Leader: School 1)

The educators also agreed that they wanted to address a range of social challenges facing young people including: the internet and social media use and safety; young people's health; anti-social behaviour; and substance (alcohol and drug) misuse:

\footnotetext{
${ }^{1}$ The Foyle Contested Space Partnership and the research for this paper was funded by Atlantic Philanthropies and the Office of the First and Deputy First Minister. All names of participants and schools have been changed.
} 
They are real issues, [the] year nine [aged 13yrs] class that you have observed, there's at least three or four of them are quite regular drinkers, and it does concern you when they are getting that young. It used to be your fourth and fifth years [aged 15/16]. [...] 'Oh, I got grounded again Miss.' 'Why?' 'I was drunk again. [...] Cyber bullying and internet safety would be a very big one. You would often get the pupils reporting incidents of the bullying and the nasty comments on Facebook and text messages, the nasty texts and stuff. The anti-social behaviour - yes, we have had incidents of some of that spilling into school - the result of them organising fights and things.' (Teacher: School 6)

All school lesson plans and resources were developed collaboratively. For practical purposes the primary schools worked together and divided themselves into two sub-partnerships. Teachers were appointed in each of the post primary schools as co-ordinators and met weekly to plan and coteach shared lessons, and manage the logistics of collaboration. The primary schools appointed a retired teacher who had taught in the city for over two decades to link all five primary schools together and work with each sub-partnership to create schemes of work and lesson plans, and distribute resources and assist during shared lessons. All primary school teachers involved in the project trained together at the beginning of each academic year and participated in evaluation activities at the end of each academic year. Principals from all the schools met every three months, as did a steering group committee of leaders, teachers, PSNI representatives, local education authorities, funders and a member of the research team.

\section{Methodology}

The study employed a multiple case study design, whereby the eight schools divided up into four sub-partnerships - two post primary groups and two primary groups were formed. Collectively the schools maintained an overarching partnership structure, operated under the same curricular and social agenda and were governed by a single leadership group made up of representatives from all eight schools.

The authors undertook ethnographic observations over a three-year period (2011-2014) in each of the case studies - visiting all schools during this period, focusing on spaces where students learned together and where educators collaborated, including: principal's offices, classrooms, gymnasiums, staff rooms, meeting rooms and outside spaces such playgrounds. Observations were also carried out at various community based venues including: youth and community centres, churches, a theatre, museums, historical sites and on buses when students travelled between schools.

Semi-structured interviews and focus groups were also held in each of the schools with leaders, teachers, partnership co-ordinators, and parents. Students in primary schools were not formally interviewed, but informal or unstructured conversations between the researcher and students were recorded (Fontana and Frey, 2005). Students in post primary schools took part in focus groups over two phases. In the first phase focus groups involved students from the same school but the second phase involved groups of students from both schools. Observations mostly occurred in years 1 and 2 and interviews and focus groups occurred in years 2 and 3.

\section{The role of the PSNI within the partnership}

The broader range of collaborative activities between schools has been reported in Duffy and Gallagher $(2015,2017)$, but this paper is concerned with the relationship that developed between the schools and the PSNI. The data will show how the school network enabled the police to engage 
positively with the Catholic schools and students, where traditionally access would have been limited or impossible.

The Foyle partnership invited the PSNI to join the steering committee and their representatives played a full role in devising an education programme based on addressing social needs across a number of domains. This extended to include PSNI officers delivering lessons in shared classrooms across the city, an approach which had not previously been undertaken in Northern Ireland. A PSNI officer described how the process evolved from discussion and agreement at the steering group level, through visits to schools to talk with teachers on how the issues could be approached, through to shared classroom visits:

I will communicate with the school, we'll sit down, we'll chat about the problems, we'll agree times and I will go into the school, or one of my colleagues, we will use resources [...] And we'll establish what lessons we're going to deliver to what particular year group. (PSNI Officer)

In shared classrooms the police tailored elements of the CASE programme to align with the priorities of the school partnership. The lessons observed included ones where the PSNI officers focused on exploring anti-social behaviour, substance misuse, internet safety and the role of the police in the community. They used a variety of strategies and resources: in some cases, a single officer spoke to students, while in in other cases a team of officers delivered sessions together. Officers brought in 'drugs boxes' containing fake illicit substances and bottles of alcohol; they used PowerPoint presentations including CCTV footage from the city; they encouraged debate and discussion, all focused on using the local context to engage students interest. All of the officers involved had undergone recognised Child Exploitation and Online Protection training (CEOP 2016) and used a variety of resources to explore online safety with young people:

Getting to know the kids in the schools, being in the schools where they're fascinated by what we're doing, they're fascinated by the videos and clips that we play them, you know, they love it, they love to see us come in. The questions that they ask us in the schools, I mean, they ask us the most obscure questions, maybe nothing to do with the lesson but they're just fascinated with the police officer being there. (PSNI Officer)

The officer also indicated that they are un-armed in the classroom and did not wear body armour in an attempt to normalise the experience of talking to students:

During these lessons I usually wear a polo shirt with the PSNI crest and the name of my neighbourhood team, green trousers, just normal uniform. I don't show a weapon, I don't show anything like that, the children don't see anything like that, which I don't think they should be able to see anything like that in schools so I try and make it as normal an experience for them as I possibly can. (PSNI Officer)

\section{The challenges}

While teachers and school leaders across the partnership were positive about the police in schools and shared classrooms, this did not come without challenges. The challenges almost exclusively arose in the Catholic schools.

\section{Access to schools}

Typically, schools informed and sought the consent of parents to undertake shared learning and held a series of events each year which encouraged parents to attend and to learn more about how 
their children were learning together. Parents were also aware that the police were delivering lessons in shared classrooms. However, the police were not able to deliver lessons in two of the Catholic schools in the partnership due to parental opposition. One PSNI officer spoke about the importance of treading lightly whilst working with the schools:

Yeah, there's at least two schools where although I have a thriving relationship with the principals of the schools and communicate with them possibly monthly, if not more than that, certainly at this point in time would not be in a position to go into the schools to deliver a lesson around internet safety or anything like this because, whether it be the Board of Governors or whoever, it's just... at this point it's too delicate, and we are aware of the Facebook sites and the other sites that really make it clear that we're not welcome in those schools at the minute. (PSNI Officer)

Some of the educators characterised the community in which the schools were located as being 'very Republican', and as such support and consent for police visits could not be achieved at this point. Staff described tensions and unrest between parents and the police and in some cases parents talked to them about being harassed or hassled by the police:

[T] here's definitely a lot more work to be done. We'd be very naïve to think that in an area like this, it's sorted. It's not. There's still a lot of unrest [...] I have still parents coming in to me in the morning and talking about how they're being hassled or harassed by the PSNI and there's very strong feelings of what can I do for the kids because the kids are distressed. (Catholic School Educator)

In one case a senior member of staff highlighted that they had tried police visits but stopped after parents had voiced their concerns:

We've had the police in once or twice before and a lot of parents weren't happy with it and came up and voiced their concern about that. (Catholic School Educator)

\section{Risks and threats}

Teachers and leaders from the Protestant schools in the partnership recognised the risks that the Catholic schools were taking by encouraging the police to visit their schools. A leader in one of the Protestant schools recognised that the risks of having police visit their school were 'minimal to nothing compared to the risks the Catholic schools were taking.' In the following transcript extract an educator from one of the Catholic schools describes how their actions and decisions are 'being watched' by people with 'strong objections' to schools being involved with the police. In this case the educator describes being threatened on a social media site:

But you see the other aspect of it is the community. You know how the choir would have sung at the PSNI carol service, you know, we've a wee choir, they really look good. [...] So they [PSNI] asked the choir to sing at the carol service. [...] On the night of the carol service I got a phone call about 5.30 to tell me that there was information on a social media site that I needed to look at. [...] The police gave us invitations to give to the pupils so that they could bring family and friends to the carol service. [...] And that evening the invite was on a certain site and a lot of stuff that was not very pleasant, including threats. So, and the decision had to be made then about whether to proceed with the carol service [...] we took the choir and there were no incidents at the cathedral. But certainly the PSNI asked me to look at the stuff online, and I saw some of it, but I didn't look at it after that, but I did tell the staff concerned what had happened. They knew what had happened anyway. So you're being watched. [...] The threats were particularly towards me anyway, there were never any threats to the children or to [the teacher], so I was fairly clear that if there were going to be any repercussions it would be to me. So I didn't feel that there was 
a risk to them. But the community can be difficult, and that's probably what you're also still seeing in the primary schools (Leader: Catholic School)

\section{Security Arrangements}

In addition to the risks some of the Catholic schools were taking by having the PSNI deliver shared lessons, there was also an issue of safety for the PSNI officers themselves. One officer talked about the risk and provided an insight into the security arrangements that needed to be put in place when delivering shared lessons in some Catholic schools:

The schools have taken very brave steps by asking us to deliver lessons on, in some cases, a weekly basis. It's a planned arranged visit at the same time every week- that presents challenges for policing. In our society we have people who haven't quite yet grasped what we're about and what we're trying to do and how society's trying to more forward and there are those within our society who are trying to take us backwards. So whenever we're in schools basically we would have at least one, if not two, security mobiles in the area [...] cars, basically. We would have people there just to ensure our safety. So, you know, we put a lot of value in what we're doing and, you know, obviously officer safety is paramount so we do put people in the area [...] The one good thing about it is, is that the car that is providing the security or the two cars that are providing the security are in the area, it is our neighbourhood beat, so they are in patrolling our area. Yes, primarily they're concerned about myself or one of my colleagues in the school at that particular time but they're not just looking at that, they're looking at other things. You know, so it's... this is the good thing about it is, it's within our area. It wouldn't be the same in other parts of the country, you know, you maybe wouldn't need that security as such, but certainly in the area I police that security is required, definitely. (PSNI Officer)

\section{The impact and benefits}

\section{The impact in shared classrooms}

Observations and interviews with teachers revealed an appreciation of the way in which the police provided guidance and support around the delivery of sensitive and controversial topics, particularly on themes such as being safe online, sexting, substance misuse and anti-social behaviour - all of which the police had received training to deliver. Teachers and school managers were also complimentary about the methods and strategies that officers used in classrooms:

Teacher S8: [...] our girls are very, very positive towards them. It's lovely to see that.

Teacher S7: And I loved their approach. [...] And I just thought that their delivery was just spot on for me. [...] I feel they had gone to a lot of effort, to produce appropriate resources. They always asked what age group are the children, and it was just very sensible.

Teacher: S6 But they have a very nice way with them, very straight.

Teacher S7: Lovely.

A teacher described the controversial nature of some of the shared lessons undertaken by the police but praised the officer's approach in the classroom:

A lot of them were quite shocked by the things they saw, you know. The drugs and alcohol, you know, the substance misuse, it's interesting for them, they do get a lot of information from it but I don't know if it changes their habits, I think it makes them think. Tom is brilliant. [...] He talked with the Year 9s and he said he wasn't telling them not to do it [drink alcohol], he said, that ship has sailed, I can't do anything about that, but I'm telling you from a police perspective it is illegal, don't 
do it. [...] But if you're going to do it, here's how to keep yourself safe and that, for me, was very good for them. (Teacher: School 6)

Observations in shared classes revealed a positive working relationship between educators and police, a pattern which was confirmed when teachers, at interview, were unanimously positive in both Catholic and Protestant schools about the presence of PSNI officers in their classrooms. In some cases, teachers in Catholic schools talked about deliberately modelling this positive relationship in classrooms so that students could see that they were comfortable with the police:

I would be overly friendly with them so the girls can see. Do you know what I mean? I like this person, I'm comfortable in this person's company, and make sure they see me laughing and joking as well with them, because I do think, they are watching you, they are watching for how you react to different people and they do take their lead from you. They trust you, and if we show them that we trust other people it relaxes them a wee bit and helps them to let down their guard. (Catholic school Leader)

It was also noteworthy that, in focus groups, young people from both community backgrounds said that the lessons delivered by the police were the most enjoyable and impactful element of the entire programme. Our analysis suggests that young people enjoyed examining the social need themes, especially substance misuse and internet safety, and they were engaged by the police use of different pedagogical approaches and resources:

S6FP1: I used to drink on the streets until the police and all came in. That's what made me stop. I don't anymore.

GD: Right. And so what's it like to have the police and community wardens coming in and talking about that kind of thing?

S6FP1: It's scary.

GD: $\quad$ So does it hit home with you?

S6FP1: Aye, it does hit home with me.

GD: $\quad$ Right. So would it have an impact?

S6FP1: Aye, definitely.

GD: Right, okay. Do you have mates or friends that maybe go out [drinking]?

S6FP1: Aye, see it's the crowds you run about with. It's the crowd I started to run about with.

S6MP1: Everybody's at it.

GD: Right. And so what's it like then to have somebody coming in and talking about this kind of thing as a subject?

S6MP1: It's good, it lets you know.

S6FP1: It's good, I enjoy it.

GD: $\quad$ Right. So you feel it's having an impact or is any of it just a waste of time and just people...?

S6MP2: Definitely not, because it's a warning more or less to what could happen to you, like with the drink and the drugs and stuff. (Case Study 3 - Shared focus group: Year 10)

\section{Improving communication and cooperation between Police and Catholic Schools}

Previously we identified some problems regarding access to two of the Catholic schools, given community opposition and the pressures put on school leaders not to allow the police into their schools. The school network provided some mitigation of this challenge. The decision to invite representatives of the police to sit on the partnership steering group was instrumental in helping the police access Catholic teachers and school leaders. Steering group meetings provided opportunities for school leaders and police officers to meet on a regular basis over the three years of the programme. While the police were unable to access two of the Catholic schools, they were 
still able to meet the Catholic teachers and leaders in other schools in the partnership, as schools took turns to host steering group meetings. By extension, where police officers were unable to access these schools they were still able to meet the Catholic children in their Protestant partner schools in a shared education setting:

It's not really about getting into that particular school, what's important is that we see the children that go to that school. And we have seen them in a shared education environment where we have introduced ourselves as police, where we have discussed the role of the police officer within our community and where we have also then discussed at the same time or in the next lesson internet safety. [...] We have met the children from those two schools in other schools within the partnership, whenever I say 'other schools' I mean a Protestant school within the partnership. [...] I would love to be in those two schools, I would love to see normalisation and for us to be in those schools as normal, however, it's more important to me that the children get the message that we're trying to put across to them. (PSNI Officer)

Evidence also emerged that Catholic schools were now more willing to co-operate in matters of normal community policing and share information. In the following transcript extract, the PSNI officer chiefly responsible for delivering shared lessons emphasises a developing relationship between him and a Catholic School Principal. As a consequence of his involvement in the partnership and visiting schools more often, the officer emerged as the point of contact, and an officer that the school trusted to talk to about students' safety or wellbeing:

I would go as far as to say [Ann] is the reason we came on board. [...] She's one of the most sincere people in relation to what she's trying to do. She'll call me at work. Last week she called me because a pupil had left school and she was, you know, really concerned that this pupil may not come back to the school and she had to suspend her, you know. And she rang me up, ["Tom], I'm really worried about this girl," and she gave me some details so I was able to go and get the wee little girl [...] I rang her back and says, ["Ann], that wee girl's safe and well and she's now with Social Services and she's heading back to where she should be," and she was delighted. She was... you can just tell by her voice, "Thank you so much for doing that for me because I needed to know the little girl was safe and well" $[\ldots]$ There was a willingness there to cooperate and work (PSNI Officer)

\section{Attitudinal change}

Participants described various changes in attitude towards the police as result of their involvement in the partnership, not just in the schools directly involved in the programme. In the following transcript extract one Catholic school leader pointed to this wider impact on schools outside of the partnership:

And you see, what you forget also is that when we were doing things here that created a pathway for other schools. Like [Mr Jones] in St [Michael's] would say that because St Agnes' had the PSNI in from day one, and that St Frances's and other schools also had them in, that he eventually was able to bring the PSNI into St Michael's. Now, this is major. But, you know, sometimes we forget that, ten years ago the PSNI up talking to St Michael's about drugs or anti-social behaviour, it's unthinkable. [...] that had ripples beyond the schools, you know, it wasn't just about what happened here. And certainly [Mr Jones] told me that he was able to bring the PSNI in on the back of the absolute normalising of the partnership with the police coming in and talking in all our schools, because his line was, "They're in all the schools, why would they not be in here?" (Leader: Catholic School) 
In the transcript extract below teachers discussed how the project had affected young people's attitudes towards the police. In this case they highlighted a developing familiarity between the police officers and the young people:

Well I just know that Tom for example, who delivers in our school, when he's up in the [nationalist area] now [on patrol duty], there's people going, "there's [Tom]!" and he's sort of hanging out the back of a Land Rover [armoured police car], "there's [Tom]!" (Catholic Teacher)

An officer corroborated the teacher perspective:

It happens so often, possibly every weekend I'm on patrol, you know, in our beat. I get kids running up to me, "You were in our school". Or if it's not me it's one of the other members of the team because we're very much team focused, and you would have the kids surround us, "You were in our school, you were telling us not to drink," (PSNI Representative)

However, the benefits deriving from visiting Catholic schools was tempered, as a teacher described a conversation with a police officer in which the officer was concerned that the level of familiarity that had developed from visiting classrooms might put young people at risk from dissident paramilitaries in the city for saying hello to a police officer:

And he said he has to pull it back a bit because he doesn't want some wee hood to say to her, "You talk to him again and you're dead." So he wants not to have that profile. [...] I'm talking in general about the impact of PSNI, but our girls are very, very positive towards them. It's lovely to see that. (Teacher: Catholic School)

While we were aware of parental opposition to the police in two Catholic schools, this opposition did not materialise from the parents who participated in the study. There was however recognition that normalised policing had not yet been achieved but that an initiative which encouraged the police to be involved in Catholic schools did go some way towards legitimising the police overtime:

Researcher: $\quad$ How do you feel about the police being involved?

Parent: Well that's one of the changes that has to be done. [...] I'd be in favour of it. I actually think that members of our community a lot more would be able to join them $[\ldots]$ that's how the thing's going to change, it has to be divided, it can't be one force for one community. If it's for everybody people has to be joining and they have to be made... It's going to take a while but that's the way it's going to start.

\section{Conclusion}

Improving the relationship between young people and police officers is generally seen as a social good, not least as it can play a role in helping to reduce crime and anti-social behaviour; improve security; make communities safer; and promote the role of the police and justice systems more broadly. Different jurisdictions have specific priorities that influence the way in which police operate in schools. In some contexts, however, relationships between the police and some communities reflect political or ethnic legacies that make positive engagement difficult. Northern Ireland is an example of this situation as the police face challenges engaging positively with Catholic schools because of difficult historical relationships between the state and the Catholic minority. A form of engagement has evolved, and positive high-level relationships have been developed, but the extent and range of engagement remains limited. 
The evidence considered in this paper demonstrates the positive impact on school-police relationships that can derive from schools working in collaborative networks. The development of collaborative networks between Protestant and Catholic schools had been intended to promote school improvement and social cohesion, mainly focused on students, teachers and parents. There was some evidence of positive impacts on wider communities, and now this paper has explored how networks can make it easier for key social institutions, such as the police, to engage positively with schools through a network. The capacity to promote positive engagement, on a range of social issues which were of direct and immediate concern to the schools and on which the PSNI had important expertise and experience, was significantly enhanced by being able to work through a network of schools. This did not obviate real security concerns for the young people and the police officers, but it did provide a wider repertoire through which positive engagement and, more important, key learning could take place safely: it also increased the range of ways in which positive engagement could be pursued and helped the police in emphasising their positive, service-oriented role.

Relationships between the police and Catholic schools evolved in the network and there was also evidence of greater levels of resource sharing, connectivity and collective enterprise between social institutions across the city. Catholic staff and students welcomed the presence of the PSNI in their schools, and officers and teachers identified mutual benefits. The presence of police officers in the classroom also had an impact in the community - young people talked about greeting officers while they were on patrol and Catholic parents who took part in the study acknowledged that the initiative was valuable.

We saw emerging evidence of a ripple effect, such that Catholic schools not in the partnership became more willing to engage with the police based on the positive interactions between the police and the Catholic schools that were in the network.

The topics addressed by the PSNI in shared classrooms were based on an agreed agenda of action identified by all the schools and agencies working together and had significant social value and relevancy for all young people irrespective of their cultural background. While this included themes such as the role of the police and the workings of the justice system, the bulk of the engagement with students focused on social and educational themes designed to keep young people healthy and safe. Officers in classrooms were not armed, nor were they in full uniform and all had been CEOP trained. Classroom observations revealed no evidence of a hidden agenda to recruit Catholics into the police force in the future. In other words, the intended focus of the work that was delivered was primarily related to the service role of the police in promoting healthy and safe lifestyles for young people.

An important benefit deriving from the network was the way in which the PSNI were able to meet Catholic students in their partner Protestant schools. A PSNI representative suggested that there was more value in being able to meet and talk to Catholic students in other settings, as compared with gaining symbolic, but potentially highly constrained, access to Catholic schools where the issue was controversial.

The case study which has provided the focus for the present paper was in an urban setting which has experienced a long legacy of political violence and division, and is one in which the traditional relationship between the police and community has been difficult. What we have seen is that, when schools from different communities work together collaboratively, not only does this help them to further their common educational goals and promote social cohesion within their local communities, but it also helps them develop creative and effective ways to 
overcome barriers to learning arising from the legacy of violence and division: in this case it has helped schools overcome the 'Patten dilemma' in which political judgements based on past experiences prevent positive service delivery in the present.

Finally, we have seen that, in other jurisdictions, positive engagement between police and schools can enhance more generally the connections between schools and communities (Frondigoun et al., 2013; Brown, 2006). Our evidence on this case study in Northern Ireland provides tantalising glimpses of the same possibilities and hints at ways the community role of the police might be further enhanced. Up to now our work on shared education has focused on the benefits for schools, teachers, students and parents arising from collaboration. There has also been a focus on the wider benefits for social cohesion from school collaboration. This case study suggests the possibility that engagement between schools and a wider range of social institutions might highlight additional social and community benefits which not only enhance social capital more generally, but significantly enhances the capacity of those social institutions to deliver their services and met their goals more effectively.

\section{References}

Akenson, D. H. (1970). The Irish education experiment: The national system of education in the nineteenth century. Routledge \& Kegan Paul.

Akenson, D. H. (1973). Education and enmity: The control of schooling in Northern Ireland 1920-1950. David \& Charles.

Bhabra, S., Hill, E., Ghate, D., Policy Research Bureau, \& United Kingdom. (2004). Safer School Partnerships: National Evaluation of the Safer School Partnerships Programme. Youth Justice Board and Department for Education and Skills. http://dera.ioe.ac.uk/7759/1/Safer\%20Schools\%20Partnerships\%20-\%20Full\%20Report.pdf

Black, C., Homes, A., Diffley, M., Sewel, K., \& Chamberlain, V. (2010). Evaluation of campus police officers in Scottish schools. Scottish Government.

http://dera.ioe.ac.uk/1225/1/0095816.pdf

Breen, S. (2011, October 9th). PSNI out: Hard-line republicans' fury at cops in schools. Sunday World.

http://www.nuzhound.com/articles/breen/arts2011/oct9_Republican_parents_fury_cops_in_scho ol_SBreen_Sunday-World.php

Brown, B. (2006). Understanding and assessing school police officers: A conceptual and methodological comment. Journal of Criminal Justice, 34(6), 591-604.

https://doi.org/10.1016/j.jcrimjus.2006.09.013

Catholic Council for Maintained Schools (2011a). Developing a Strategic Partnership between the PSNI and Catholic Maintained Schools CCMS Circular 2011/20. CCMS. 
http://onlineccms.com/index.php/publications/ccms-circulars/ccms-circulars-2011/2011-20ccms-psni-strategic-partnership

Catholic Council for Maintained Schools (2011b). Developing a Strategic Partnership between the PSNI and Catholic Maintained Schools CCMS Circular 2011/27. CCMS.

http://onlineccms.com/index.php/publications/ccms-circulars/ccms-circulars-2011/2011-27-developinga-strategic-partnership-between-psni-and-catholic-maintained-schools

Clayman, S., \& Skinns, L. (2012). To snitch or not to snitch? An exploratory study of the factors influencing whether young people actively cooperate with the police. Policing and Society, 22(4), 460-480. https://doi.org/10.1080/10439463.2011.641550

Council for the Curriculum Examination and Assessment (2016). Personal Development and Mutual Understanding for Key Stages $1 \& 2$. CCEA.

http://ccea.org.uk/sites/default/files/docs/curriculum/area of learning/pdmu/ks1 2 pdmu guida nce.pdf

Council for the Curriculum Examination and Assessment (2016a) Learning for Life and Work for Key Stage 3. CCEA.

http://ccea.org.uk/sites/default/files/docs/curriculum/area of learning/learning life work/ks3 11 w guidance.pdf

Devaney, Lee., Pehrson, S., Bryan, D., and Blaylock, D. (2014) The Dynamics of Police Legitimacy Among Young People. The NI Executive Office. https://www.executiveofficeni.gov.uk/publications/dynamics-police-legitimacy-among-young-people

Duffy, G. \& Gallagher, T. (2014). Sustaining school partnerships: The context of cross-sectoral collaboration between schools in a separate education system in Northern Ireland. Review of Education, 2(2) 189-210. https://doi.org/10.1002/rev3.3034

Duffy, G. \& Gallagher, T. (2015). Collaborative evolution: The context surrounding the formation and the effectiveness of a school partnership in a divided community in Northern Ireland. Research Papers in Education, 30(1), 1-24.

https://doi.org/10.1080/02671522.2014.880731

Duffy, G. \& Gallagher, T. (2017). Shared Education in contested spaces: How collaborative networks improve communities and schools. Journal of Educational Change, 18, 1-28. https://doi.org/10.1007/s10833-016-9279-3

Education Act (Northern Ireland) 2014. (2014). The Stationery Office. http://www.legislation.gov.uk/nia/2014/12/contents.

Ellison, G. (2000). Reflecting all shades of opinion. British journal of criminology, 40(1), 88111. https://doi.org/10.1093/bjc/40.1.88 
Ellison, G., \& Mulcahy, A. (2001). Policing and social conflict in Northern Ireland. Policing and Society: An International Journal, 11(3-4), 243-258.

https://doi.org/10.1080/10439463.2001.9964865

Frondigoun, L., Smith, R., \& MacLeod, I. (2013). The Scottish Campus Officer: Past, Present and Future. Scottish Institute for Policing Research. https://research-

portal.uws.ac.uk/en/publications/the-scottish-campus-officer-past-present-and-future

Gallagher, T. (2004). Education in divided societies. Palgrave Macmillan.

https://doi.org/10.1057/9780230536722

Gallagher, T. (2016). Shared education in Northern Ireland: school collaboration in divided societies. Oxford Review of Education, 1-14. https://doi.org/10.1080/03054985.2016.1184868

Gallagher, T., \& Duffy, G. (2016). Recognising difference while promoting cohesion: The role of collaborative networks in education. In I. Honohan, \& N. Rougier (Eds.). Tolerance and diversity in Ireland. North and South (pp35-54). Manchester University Press.

https://doi.org/10.7765/9781784997182.00011

Hamilton, J., Radford, K., \& Jarman, N. (2003). Policing, accountability, and young people. Belfast: Institute for Conflict Research. http://conflictresearch.org.uk/reports/policing/NIPBPONI-Young-People-April-2003.pdf

Hopkins, N. (1994). School pupils' perceptions of the police that visit schools: Not all police are 'pigs'. Journal of Community \& Applied Social Psychology, 4(3), 189-207. https://doi.org/10.1002/casp.2450040306

Hopkins, N., Hewstone, M., \& Hantzi, A. (1992). Police-Schools Liaison and young people's image of the police: An intervention evaluation. British Journal of Psychology, 83(2), 203-220. https://doi.org/10.1111/j.2044-8295.1992.tb02435.x

Hughes, J., \& Loader, R. (2015). 'Plugging the gap': shared education and the promotion of community relations through schools in Northern Ireland. British Educational Research Journal, 41(6), 1142-1155. https://doi.org/10.1002/berj.3206

James, N., \& McCallion, G. (2013). School resource officers: Law enforcement officers in schools. Congressional Research Service. https://fas.org/sgp/crs/misc/R43126.pdf

Lamont, E., Macleod, S., \& Wilkin, A. (2011). Police Officers in Schools: A scoping study. NFER Report. https://www.nfer.ac.uk/publications/PCOX01/PCOX01.pdf

Loader, R. M. (2015). Shared education in Northern Ireland: A qualitative study of intergroup contact [Unpublished Doctoral Dissertation]. Queen's University Belfast. 
Na, C., \& Gottfredson, D. C. (2013). Police officers in schools: Effects on school crime and the processing of offending behaviors. Justice Quarterly, 30(4), 619-650.

https://doi.org/10.1080/07418825.2011.615754

Nelson, E., McBride, R.S., O’Riordan, O., \& Smyth, P. (2010) Beyond the margins: Building trust in policing and young people. Belfast, UK: Achieve Enterprises and Institute for Conflict Research. http://conflictresearch.org.uk/reports/policing/Beyond-the-Margins-Building-Trust-inPolicing-With-Young-People.pdf

Nelson, J. (2013). Common education and separate schools: A study of sharing education in Northern Ireland using a grounded theory methodology [Unpublished Doctoral Dissertation]. Queen's University Belfast.

Northern Ireland Statistics and Research Agency (2007) Young Person's Behaviour and Attitudes Survey. NISRA. https://www.nisra.gov.uk/statistics/young-persons-behaviour-attitudessurvey

Patten, C. (1999). A New Beginning: Policing in Northern Ireland. The Report of the Independent Commission on Policing for Northern Ireland. The Stationery Office. https://cain.ulster.ac.uk/issues/police/patten/patten99.pdf

Petteruti, A. (2011). Education under arrest: The case against police in schools. Justice Policy Institute. http://www.justicepolicy.org/EducationUnderArrest

Police Service for Northern Ireland. (2009). Equality Impact Assessment: Citizenship and Safety Education (CASE) Programme Final Report. PSNI. https://www.psni.police.uk/inside-psni/ourpolicies-and-procedures/equality-diversity-and-good-relations/eqia-consultation-zone/eqiaarchive/

Police Service for Northern Ireland (2007) Youth Strategy Book. (PB2165/07). PSNI. https://www.psni.police.uk/globalassets/inside-the-psni/how-we-are-working-our-youngpeople/documents/youth_strategy.pdf

Police Service for Northern Ireland. (2016) Engagement with young people. https://www.psni.police.uk/inside-psni/working-with-our-young-people/engagement-withyoung-people/

Robinson, G. (2016) A Social Network Analysis of Interschool Collaboration: Staff Relationships In a Shared Education Partnership [Unpublished Doctoral Dissertation]. Queen's University Belfast.

Stead, J. Lloyd, G. Baird, A. Brown, J. Riddell, S. Weedon, E and Laugharne, J. (2011). All Wales School Liaison Core Programme (AWSLCP) Evaluation Report. Welsh Government. http://dera.ioe.ac.uk/13168/1/110314allwalesschoolliaisoncoreprogrammeen.doc 
Stinson, P. M., \& Watkins, A. M. (2014). The Nature of Crime by School Resource

Officers. SAGE Open, 4(1), 1-10 https://doi.org/10.1177\%2F2158244014521821

Taggart, M. (2011). Police in Catholic schools bid to break down barriers. British Broadcasting Corporation. http://www.bbc.co.uk/news/uk-northern-ireland-15115386

The Everytown Research Group (2016) Analysis of School Shootings Jan 1st 2013 - Dec $31^{\text {st }}$ 2015. https://everytownresearch.org/school-shootings/

The Police Foundation. (2011). 'Safer school partnerships', The Briefing, 2(2), November 2011. The Police Foundation. http://www.police-foundation.org.uk/2017/wpcontent/uploads/2017/08/safer schools briefing.pdf

Theriot, M. T. (2009). School resource officers and the criminalization of student behavior. Journal of Criminal Justice, 37(3), 280-287. https://doi.org/10.1016/j.jcrimjus.2009.04.008

Trotman, D., \& Thomas, L. (2016). Police community support officers in schools: Findings from an evaluation of a pilot training programme for school liaison officers. Policing: A Journal of Policy and Practice, 10(3), 288-299. https://doi.org/10.1093/police/paw006

Zhang, A., Musu-Gillette, L., \& Oudekerk, B. A. (2016). Indicators of School Crime and Safety: 2015. NCES 2016-079/NCJ 249758. National Center for Education Statistics.

https://nces.ed.gov/pubs2016/2016079.pdf 